\title{
Changes in rat testicular adenylate cyclase activities and gonadotrophin binding during unilateral experimental cryptorchidism
}

\author{
T. Jahnsen, J. O. Gordeladze, E. Haug* and V. Hansson \\ Institute of Pathology, Rikshospitalet, and ${ }^{*}$ Hormone Laboratory, Aker Hospital, Oslo, Norway
}

\begin{abstract}
Summary. Unilaterally cryptorchid rats were examined at 3, 8, 15, 22 and 28 days after operation. There was a selective decrease in the adenylate cyclase (ATP pyrophosphate-lyase (cyclizing), EC 4.6.1.1) responses to gonadotrophin stimulation in the abdominal testis. This was associated with a parallel decrease in specific FSH and LH binding. There was no reduction in the response of testicular adenylate cyclases to prostaglandin (PG) E-1 or fluoride stimulation, indicating that both the GTP binding protein (N-component) and the catalytic subunit of the adenylate cyclase complexes were intact.

The reduction in FSH-responsive adenylate cyclase activity in the abdominal testis was not due to a change in the $K_{\mathrm{m}}$ for adenylate cyclase activation, but was due to a reduction in maximal velocities.

Unilateral cryptorchidism was also associated with a rapid decline in soluble $\mathrm{Mn}^{2+}$-dependent adenylate cyclase activity in germ cells (spermatids). By 3 days after operation there was an $82 \%$ decrease in germ cell adenylate cyclase activity. The loss of soluble $\mathrm{Mn}^{2+}$-dependent adenylate cyclase activity was associated with a parallel decrease in Sertoli cell secretion of androgen binding protein, indicating that Sertoli cell factors may be important for the maintenance of germ cell adenylate cyclase activity. The desensitization of the gonadotrophin-responsive adenylate cyclases and the loss of gonadotrophin receptors in Leydig and Sertoli cells were not due to changes in plasma gonadotrophin values because LH concentrations were within normal limits and plasma FSH was only marginally elevated in the cryptorchid rats.

No significant alterations of any of these parameters were seen in the scrotal testis of unilaterally cryptorchid rats when compared to values for intact controls.
\end{abstract}

\section{Introduction}

Cryptorchidism is associated with impairment of spermatogenesis, indicating the heat sensitivity of the testicular germ cells. The Sertoli cells and Leydig cells were for a long time assumed to remain functionally intact during cryptorchidism. However, the Sertoli cell secretion of androgen binding protein (ABP) is decreased by cryptorchidism (Hagenäs \& Ritzen, 1976), and this decrease is associated with a comparable decrease in specific FSH receptors (Hagenäs, Ritzen, Svensson, Hansson \& Purvis, 1978). The Leydig cells also undergo distinct alterations during cryptorchidism (Kerr, Rich \& de Krester, 1979). LH receptors are decreased (Hagenäs et al., 1978; de Kretser, Sharpe \& Swanston, 1979) and the Leydig cells show hypertrophy and increased quantities of intracellular organelles (mitochondria and smooth endoplasmic reticulum) 
(Kerr et al., 1979). Since gonadotrophin levels are increased during bilateral cryptorchidism a possible explanation for these findings could be that the elevated serum levels of FSH and LH caused down-regulation of their specific receptors and ultimately target cell desensitization (de Kretser et al., 1979). However, the fact that testicular gonadotrophin receptors and ABP secretion show similar changes, even during unilateral cryptorchidism (Hagenäs et al., 1978) in the presence of normal circulating levels of gonadotrophins and steroids, excludes the possibility that the reported changes are due to the elevated gonadotrophin levels.

We have previously demonstrated that membrane particulate fractions from adult rat testes contain both FSH and $\mathrm{LH} / \mathrm{hCG}$ responsive adenylate cyclases (Jahnsen, Purvis, Birnbaumer \& Hansson, 1980a; Jahnsen \& Hansson, 1980). In addition, testicular germ cells contain a cell specific adenylate cyclase exclusively localized to haploid cells (Braun \& Dods, 1975; Gordeladze, Purvis, Clausen, Rommerts \& Hansson, 1981). In the present study with unilaterally cryptorchid rats we have examined the changes in $\mathrm{Mn}^{2+}$-dependent soluble adenylate cyclase activities of germ cells and the responsiveness of Sertoli cell and Leydig cell adenylate cyclases and compared the results to changes in LH and FSH receptor values, plasma FSH and LH concentrations and Sertoli cell secretion of ABP.

\section{Materials and Methods}

\section{Animals}

Thirty male Sprague-Dawley rats were used. Twenty of the rats were made unilaterally cryptorchid at 66 days of age, and the other 10 animals were used as controls.

The rats were anaesthetized with a subcutaneous injection of fentanyl $(0.06 \mathrm{mg})$ and fluanisone (2 mg) (Hypnorm: Aktiebolaget Mekos, Helsingborg, Sweden) and a midline abdominal incision was made. The right testis was fixed to the lateral abdominal wall $0.5 \mathrm{~cm}$ above the umbilicus with a suture through the tunica albuginea. At 3, 8, 15, 22 and 28 days after the operation 4 cryptorchid and 2 control rats were killed and blood samples were collected from the jugular vein into tubes pretreated with heparin. The blood was centrifuged $(1500 \mathrm{~g}, 10 \mathrm{~min}$, $4^{\circ} \mathrm{C}$ ), and the plasma samples were stored at $-70^{\circ} \mathrm{C}$ until assayed for $\mathrm{FSH}$ and $\mathrm{LH}$. The testes and epididymides were removed, placed on ice, dissected free of connective tissue and fat, and weighed. Seminiferous tubules were dissected in Eagles medium using the method of Christensen \& Mason (1965) at room temperature. The isolated seminiferous tubules were collected and weighed. FSH, LH/hCG, prostaglandin (PG) E-1 and fluoride-responsive adenylate cyclase activities as well as FSH and LH binding were measured in testis membrane particles, and $\mathrm{Mn}^{2+}$-dependent soluble adenylate cyclase activity was measured in testis cytosol. ABP was measured in epididymal cytosol.

\section{Preparation of particulate and cytosol fractions}

The membrane particulate fractions were prepared from whole testis tissue or seminiferous tubules by homogenization in 20 volumes (with respect to the initial tissue weight) of TE-buffer (10 mM-Tris- $\mathrm{HCl}, 1 \mathrm{~mm}$-EDTA, $\mathrm{pH} \mathrm{7.4)} \mathrm{and} \mathrm{filtered} \mathrm{through} \mathrm{a} \mathrm{nylon} \mathrm{mesh.} \mathrm{The} \mathrm{homogenate}$ was then centrifuged at $27000 \mathrm{~g}$, for $30 \mathrm{~min}$ at $0-4^{\circ} \mathrm{C}$. The pellet was resuspended in 20 volumes of TE-buffer, and re-centrifuged as described above. The final pellet was resuspended in 10 volumes of TE-buffer containing $0.1 \%$ bovine serum albumin (BSA). These membrane particle suspensions were used for measurements of FSH, LH/hCG, PGE-1 and fluoridesensitive adenylate cyclase activities and specific FSH and LH binding. Details of the procedure for tissue homogenization and preparation of the membrane particulate fractions for hormone-sensitive adenylate cyclase assay and binding studies have been published previously (Jahnsen et al., 1980a; Jahnsen, Gordeladze, Torjesen \& Hansson, 1980b). 
Adenylate cyclase assay

The assay of particulate adenylate cyclase activity in rat testis tissue has been described previously (Jahnsen et al., 1980a). In brief, membrane particle suspensions (20 $\mu$ l, 35-70 $\mu \mathrm{g}$ protein per assay tube) from whole testis tissue or seminiferous tubules were examined for adenylate cyclase activity in a final volume of $50 \mu$. Each assay tube contained $0.55 \mathrm{mM}$-ATP (including $2.3 \times 10^{6}-3.2 \times 10^{6}$ c.p.m. $\left[\alpha^{32} \mathrm{P}\right] \mathrm{ATP}$ ), $0.04 \mathrm{mM}-\mathrm{GTP}, 3.5 \mathrm{mM}-\mathrm{MgCl}_{2}, 1$ mM-cAMP (including 12000-15000 c.p.m. [8- $\left.{ }^{3} \mathrm{H}\right] \mathrm{cAMP}$ ), 1 mM-EDTA and ATP regenerating system consisting of creatine phosphate $(20 \mathrm{mM})$, creatine kinase $(0.2 \mathrm{mg} / \mathrm{ml})$ and myokinase $(0.02 \mathrm{mg} / \mathrm{ml})$ in $25 \mathrm{~mm}$-Tris- $\mathrm{HCl}$ buffer, $\mathrm{pH} 7.3$. If not otherwise stated, the incubations were carried out in the absence or presence of $4 \mu \mathrm{g}$ human FSH $/ \mathrm{ml}(15000 \mathrm{i} . \mathrm{u} . / \mathrm{mg}$ by RIA; this FSH preparation $\left(\mathrm{PT}_{2}\right)$ was a gift from P. Torjesen, Hormone Laboratory, Aker Hospital, Oslo), $1 \mu \mathrm{g} \mathrm{hCG} / \mathrm{ml}$ (Physex; Leo, Denmark), $10 \mu \mathrm{g}$ PGE-1/ml (gift from Dr J. Pike, The Upjohn Company, U.S.A.) or $10 \mathrm{mM}-\mathrm{F}^{-}$at $35^{\circ} \mathrm{C}$ for $12 \mathrm{~min}$. Cyclic AMP was isolated by Dowex and alumina chromatography (Salomon, Londos \& Rodbell, 1974) with the modifications described by Birnbaumer, Yang, Hunzicker-Dunn, Bockaert \& Duran (1976).

Germ cell adenylate cyclase activity in cytosol fractions (20-30 $\mu \mathrm{g}$ protein per assay tube) was measured essentially as described for membrane particle suspensions except that 5 $\mathrm{mM}-\mathrm{MnCl}_{2}$ was used instead of $3.5 \mathrm{mM}-\mathrm{MgCl}_{2}$. This assay has been described elsewhere (Gordeladze \& Hansson, 1980).

\section{Measurements of FSH and LH binding}

Specific FSH and LH binding was estimated as described by Hansson et al. (1978) by equilibrating aliquots of the testicular membrane particulate fractions with ${ }^{125}$ I-labelled hFSH or ${ }^{125}$ I-labelled hLH in a total volume of $200 \mu l$.

\section{Measurements of gonadotrophins}

Plasma concentrations of LH and FSH were determined by the radioimmunoassay kits from the National Institute of Arthritis, Metabolic and Digestive Diseases, Bethesda, Maryland, U.S.A. The gonadotrophins were labelled with ${ }^{125}$ I using the Enzymobead reagent from Bio-Rad Laboratories, California, U.S.A., consisting of lactoperoxidase and glucose oxidase covalently coupled to derivatized polyacrylamide spheres. The specific activity was $100-150 \mu \mathrm{Ci} / \mu \mathrm{g}$. Separation of bound and free hormone was performed using a double-antibody solid-phase method (Haug \& Gautvik, 1976). The assay sensitivity was $7 \mathrm{ng} /$ tube (corresponding to 70 $\mathrm{ng} / \mathrm{ml}$ plasma) for $\mathrm{LH}$ and $20 \mathrm{ng} /$ tube (corresponding to $100 \mathrm{ng} / \mathrm{ml}$ plasma) for FSH, respectively. Within-assay precision was $<10 \%$ and the between-assay precision was $<15 \%$ for both assays.

\section{Measurement of epididymal $A B P$}

Epididymal cytosol $(250 \mu \mathrm{l})$ prepared in $10 \mathrm{mM}$-Tris-HCl buffer, $(\mathrm{pH} 7.4)$ containing 100 $\mathrm{mM}-\mathrm{CaCl}_{2}$ and $10 \%$ glycerol was subjected to steady-state polyacrylamide gel electrophoresis as described by Ritzén, French, Weddington, Nayfeh \& Hansson (1974).

\section{Statistics}

Statistical analysis of the data was performed using Wilcoxon's two-sample rank test (two-tailed test). Since there were no significant differences between the five control groups, these observations were pooled into one group during the analysis to facilitate a more precise 
statistical evaluation. Hence the data from the 4 abdominal or 4 scrotal testis were compared with data from all 10 control rats.

\section{Miscellaneous}

The protein contents of the membrane particle suspensions and cytosol fractions were measured by the technique of Lowry, Rosebrough, Farr \& Randall (1951). The ATP and GTP concentrations used were calculated by u.v.-light spectrophotometry at $260 \mathrm{~nm}$.

\section{Results}

Table 1 summarizes the testicular and epididymal weights for the control and unilaterally cryptorchid rats at various times after the operation.

Table 1. Testicular and epididymal weights (mean \pm s.d.) in the control and unilaterally cryptorchid rats at different times after the operation

\begin{tabular}{lcccc}
\hline & $\begin{array}{c}\text { Days after } \\
\text { operation }\end{array}$ & $\begin{array}{c}\text { No. of } \\
\text { rats }\end{array}$ & $\begin{array}{c}\text { Testicular } \\
\text { wt }(\mathrm{g})\end{array}$ & $\begin{array}{c}\text { Epididymal } \\
\text { wt (g) }\end{array}$ \\
\hline Control rats & 3 & 2 & $1.85 \pm 0.18$ & $0.50 \pm 0.04$ \\
& 8 & 2 & $1.80 \pm 0.18$ & $0.51 \pm 0.01$ \\
& 15 & 2 & $1.73 \pm 0.14$ & $0.44 \pm 0.02$ \\
& 22 & 2 & $1.88 \pm 0.13$ & $0.46 \pm 0.03$ \\
& 28 & 2 & $1.85 \pm 0.08$ & $0.57 \pm 0.04$ \\
\hline Unilaterally cryptorchid rats & & & & \\
Scrotal testis side & 3 & 4 & $1.74 \pm 0.20$ & $0.45 \pm 0.06$ \\
& 8 & 4 & $1.75 \pm 0.05$ & $0.49 \pm 0.05$ \\
& 15 & 4 & $1.90 \pm 0.11$ & $0.57 \pm 0.04$ \\
& 22 & 4 & $1.82 \pm 0.17$ & $0.59 \pm 0.03$ \\
& 28 & 4 & $1.79 \pm 0.21$ & $0.56 \pm 0.08$ \\
Abdominal testis side & 3 & 4 & $1.49 \pm 0.21$ & $0.43 \pm 0.06$ \\
& 8 & 4 & $0.62 \pm 0.07$ & $0.64 \pm 0.20$ \\
& 15 & 4 & $0.53 \pm 0.07$ & $0.33 \pm 0.03$ \\
& 22 & 4 & $0.50 \pm 0.08$ & $0.41 \pm 0.12$ \\
& 28 & 4 & $0.44 \pm 0.05$ & $0.31 \pm 0.06$ \\
\hline
\end{tabular}

The seminiferous tubules of the cryptorchid testes showed reduced adenylate cyclase responsiveness to FSH compared to those of the scrotal testes and the testes from control animals; the reduced responsiveness was not due to alterations in the $K_{\mathrm{m}}$, but to a reduction in maximal velocity (Text-fig. 1). The $K_{\mathrm{m}}$ values $(50,52$ and $72 \mathrm{ng} / \mathrm{ml}$ in abdominal, scrotal and control testes, respectively) were of the same magnitude as reported for the same FSH preparation in earlier studies (Jahnsen et al., 1980a). Similar $K_{\mathrm{m}}$ values were also achieved at longer periods (8-28 days) of cryptorchidism although the purity of the tubule preparations was less and the responses much lower (data not shown).

After 3 days of unilateral cryptorchidism there was a significant reduction in the adenylate cyclase responsiveness to FSH in abdominal testes $(P<0.01)$, and the responsiveness continued to fall during the 28 days of observation (Text-fig. 2a). The activity of the FSH-responsive adenylate cyclase in scrotal testes was unaffected and did not significantly differ from that in control rats. The adenylate cyclase responsiveness to $\mathrm{LH} / \mathrm{hCG}$ was significantly reduced in the abdominal testis after 8 days (Text-fig. 2b). In scrotal testes the response to LH/hCG was not different from that in the control animals. Neither the PGE-1-responsive adenylate cyclase nor 


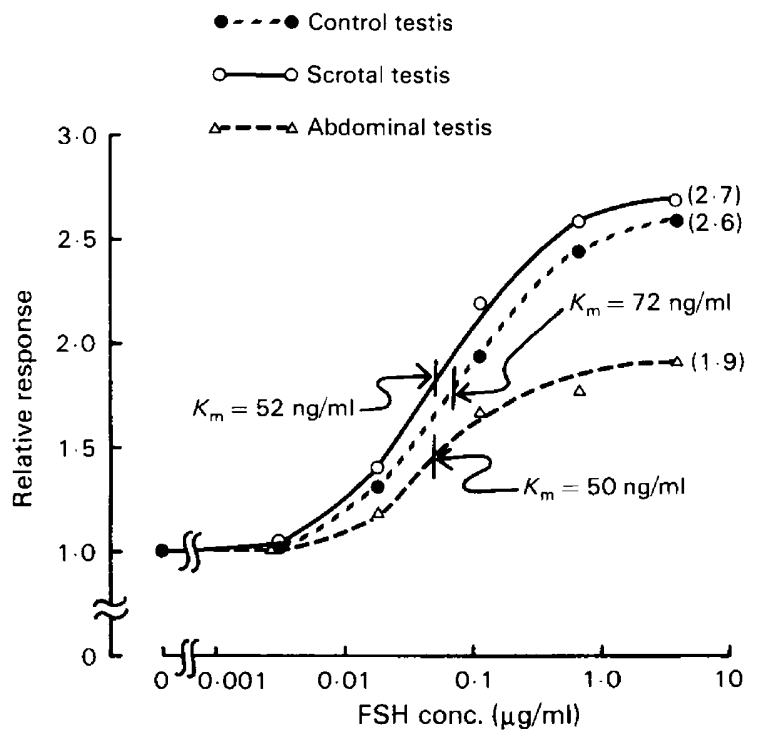

Text-fig. 1. Dose-response curves showing the responsiveness of FSH-responsive adenylate cyclase in seminiferous tubular membrane particles of abdominal and scrotal testes from rats which had been unilaterally cryptorchid for 3 days, and testes from control rats. Each point represents the mean of duplicate determinations. The relative response is calculated from the FSH-stimulated adenylate cyclase activity divided by basal adenylate cyclase activity. Basal activities were $1.5 \pm 0.0,1.4 \pm 0.3$ and $1.3 \pm 0.1 \mathrm{pmol} \mathrm{cAMP}$ formed $/ \mathrm{mg}$ protein $\mathrm{min}^{-1}$ for abdominal, scrotal and control testes, respectively. The numbers in parentheses indicate the maximal relative responses. The $K_{\mathrm{m}}$ values are those for the concentration of hFSH giving $50 \%$ maximal response.

the fluoride-responsive adenylate cyclase was influenced in the cryptorchid testis (Text-figs $2 \mathrm{c}$ and $2 \mathrm{~d}$ ).

In agreement with previous results (Hagenäs et al., 1978), there was a time-dependent decrease in specific FSH and LH binding in the abdominal testis (Text-fig. 3). The observed decrease in gonadotrophin receptors and adenylate cyclase responsiveness to FSH and LH/hCG was not due to changes in circulating gonadotrophins, because plasma FSH and LH concentrations (Text-fig. 4) were generally undisturbed by the treatment.

The activity of soluble $\mathrm{Mn}^{2+}$-dependent adenylate cyclase in haploid germ cells was reduced from 33 to $6 \mathrm{pmol} \mathrm{cAMP}$ formed/min and $\mathrm{mg}$ protein within the first 3 days after the operation (Text-fig. 5). By 8 days the activity was completely lost. The $\mathrm{Mn}^{2+}$-dependent adenylate cyclase in scrotal testes did not differ from that in the testes of control animals.

There was a rapid loss of ABP from the cryptorchid epididymis and no ABP was measurable after 2 weeks of cryptorchidism (Text-fig. 6). ABP levels in the scrotal epididymides was not significantly different from that in control rats.

\section{Discussion}

In the present study we have investigated the effect of unilateral cryptorchidism on gonadotrophin-, PGE-1- and fluoride-stimulated adenylate cyclases, soluble $\mathrm{Mn}^{2+}$-dependent germ cell adenylate cyclase, and gonadotrophin binding in rat testes. The data show that there is a selective desensitization of gonadotrophin-responsive adenylate cyclases in the abdominal testis when compared to the scrotal testis of the same animal or to testes from normal controls. The decreased responsiveness of the adenylate cyclases to FSH and LH/hCG stimulation was 
(a) FSH

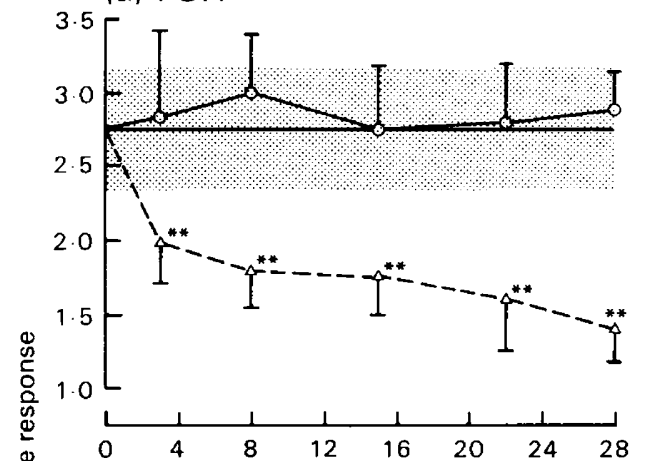

(c) PGE-1

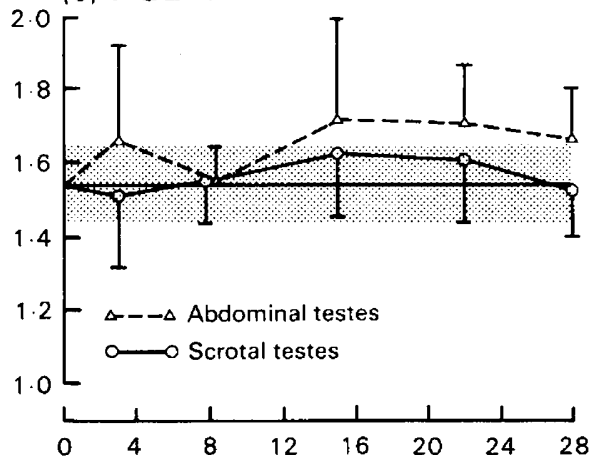

(b) hCG

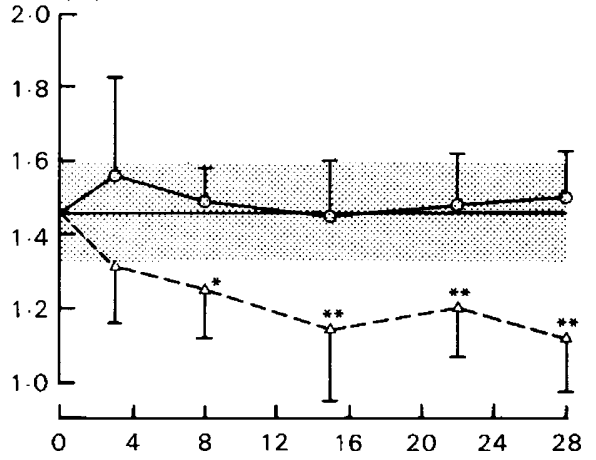

(d) $\mathrm{F}^{-}$

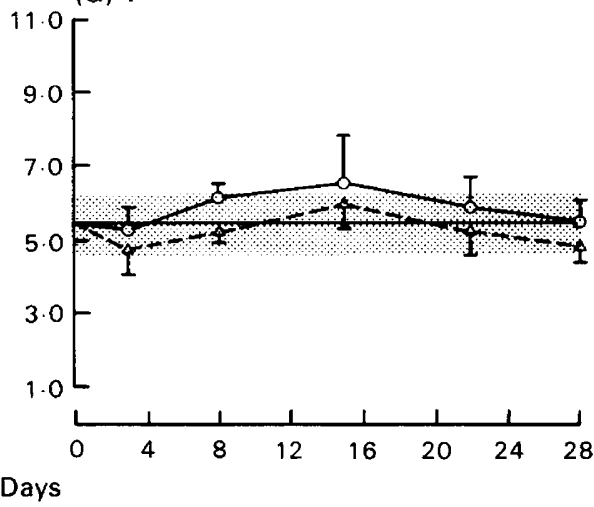

Text-fig. 2. Changes (mean \pm s.d. for 4 testes) in adenylate cyclase activities (stimulated activities relative to basal activities) responsive to (a) FSH, (b) hCG, (c) PGE-1 and (d) fluoride in whole testis tissue membrane particles from abdominal and scrotal testes of unilaterally cryptorchid rats. The shaded area indicates the mean \pm s.d. of the 10 control animals. Basal activity (pmol cAMP formed/mg protein $\mathrm{min}^{-1}$ ) was $2 \cdot 1 \pm 0.4$ in control testes and at $3,8,15$, 22 and 28 days after operation the values were, respectively, $2.4 \pm 0.5,3.5 \pm 0.1,2.9 \pm 0.4$, $3.0 \pm 0.2$ and $2.8 \pm 0.4$ in abdominal testes and $2.0 \pm 0.4,2.2 \pm 0.5,1.8 \pm 0.5,2.4 \pm 0.3$ and $1.9 \pm 0.3$ in scrotal testes. Relative responses significantly different from the control values are indicated: ${ }^{*} P>0.05,{ }^{* *} P<0.01$ (Wilcoxon rank test).

paralleled by a similar reduction in the concentration of gonadotrophin receptors. Normal fluoride-stimulated adenylate cyclase activities in the abdominal testis indicate that cryptorchidism is probably not associated with alterations in the GTP binding protein or the catalytic subunit of the adenylate cyclase, since it is generally accepted that fluoride stimulates the adenylate cyclase through the GTP binding protein of the adenylate cyclase complex (Eckstein, Cassel, Levkovitz, Lowe \& Selinger, 1979; Downs, Spiegel, Singer, Reen \& Aurbach, 1980). The finding that decreased gonadotrophin responsiveness of the adenylate cyclases was paralleled by a reduction in gonadotrophin receptors made it tempting to postulate that during unilateral cryptorchidism only the gonadotrophin receptors of the receptor-adenylate cyclase complex are lost. The decreased concentration of gonadotrophin receptors and the reduced adenylate cyclase responsiveness to gonadotrophins found in the abdominal testis resemble desensitization of membrane-bound adenylate cyclase systems seen after exposure to high levels of homologous hormone (Hsueh, Dufau \& Catt, 1977; Jahnsen et al., 1980b; Jahnsen, Purvis, Torjesen \& Hansson, 1980c).

De Kretser et al. (1979) have proposed that the reduction in $\mathrm{LH}$ binding seen during cryptorchidism may be due to the elevated concentrations of homologous hormone because LH 

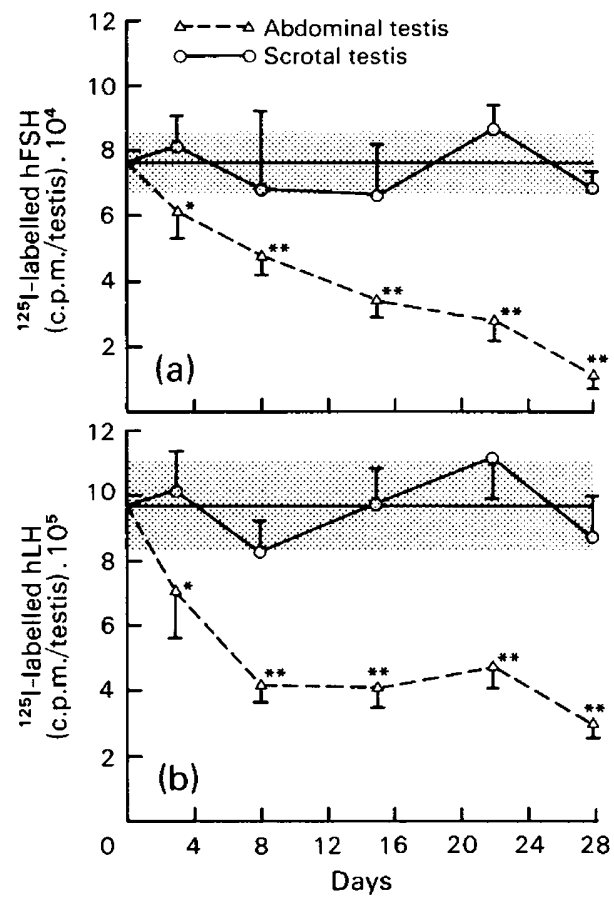

Text-fig. 3. Specific binding of (a) FSH and (b) $\mathrm{LH}$ in abdominal and scrotal testes of unilaterally cryptorchid rats. The shaded area indicates the mean \pm s.d. of the 10 control animals. Each point represents the mean \pm s.d. for 4 testes. Values significantly different from control values are indicated: ${ }^{*} P<0.05,{ }^{* *} P<0.01$ (Wilcoxon rank test).
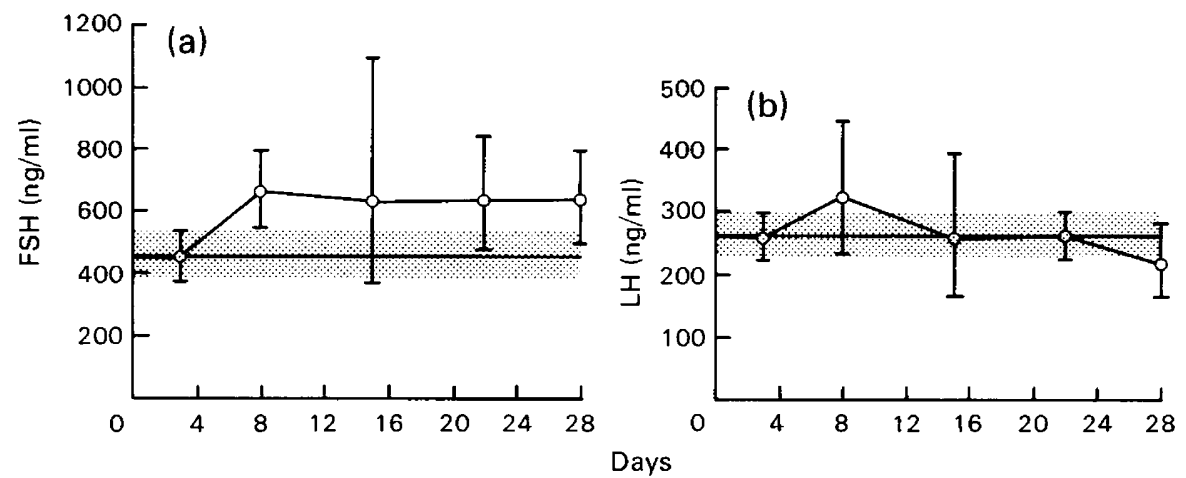

Text-fig. 4. Plasma concentrations of (a) FSH and (b) LH in unilaterally cryptorchid rats. Each point represents the geometric mean and the bars indicate $95 \%$ confidence limits for data from 4 animals. The shaded areas indicate the geometric mean and $95 \%$ confidence limits of plasma FSH and LH levels in 10 control animals.

values are increased considerably during bilateral cryptorchidism (Amatayakul, Ryan, Vozumi \& Albert, 1971; Walsh \& Swerdloff, 1973; Gupta, Rager, Zarzycki \& Eichner, 1975; Gomes \& Jain, 1976; de Kretser et al., 1979; Kerr et al., 1979). However, in a previous study (Hagenäs et $a l ., 1978$ ) as well as in this report there was a decrease in LH and FSH binding during unilateral cryptorchidism although circulating LH and FSH values were normal. Another fact indicating that elevated plasma gonadotrophin levels are not involved in desensitization of the FSH- and LH/hCG-responsive adenylate cyclase and loss of their respective membrane receptors is that 


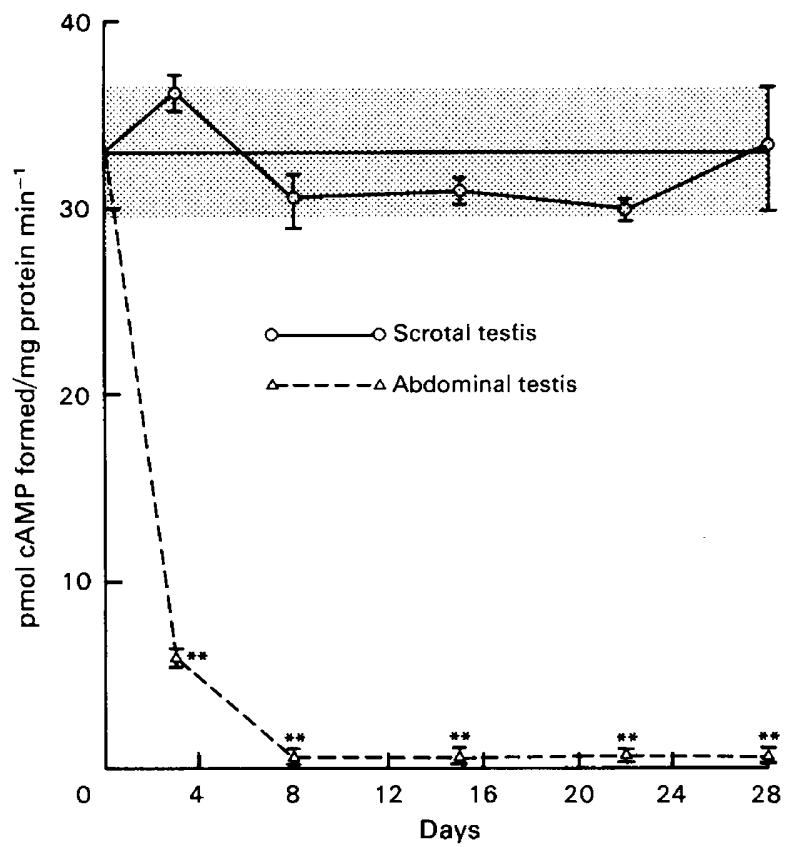

Text-fig. 5. Soluble $\mathrm{Mn}^{2+}$-dependent adenylate cyclase activities (mean \pm s.d. for 4 testes) in abdominal and scrotal testes of unilaterally cryptorchid rats. The shaded area is the mean \pm s.d. for 10 control animals. Values significantly different from control values are indicated: ${ }^{* *} P<$ 0.01 (Wilcoxon rank test).

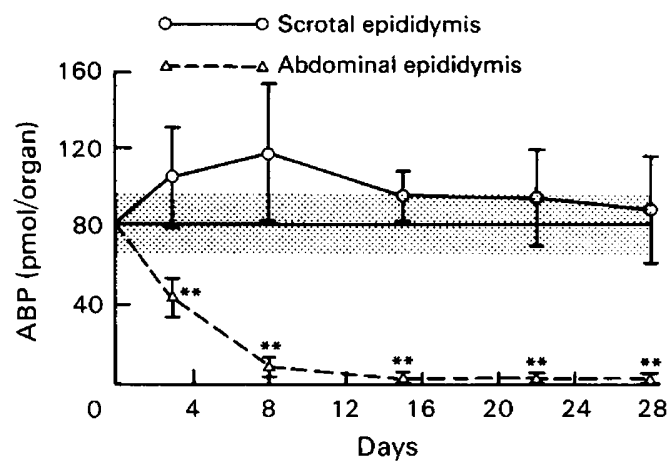

Text-fig. 6. Androgen binding protein (ABP) contents (mean \pm s.d. for 4 epididymides) of the abdominal and scrotal epididymis of unilaterally cryptorchid rats. The shaded area is the mean \pm s.d. for 10 control animals. Values significantly different from control values are indicated: ${ }^{* *} P<0.01$ (Wilcoxon rank test).

both hormone receptors and adenylate cyclase responses were normal in the scrotal testis of the same animals. In these experiments we must assume that both the abdominal and the scrotal testes are exposed to the same levels of circulating hormones.

The finding of a rapid decrease in both $\mathrm{Mn}^{2+}$-dependent adenylate cyclase activity and ABP secretion supports the speculation that secretory products from the Sertoli cells may be important for maintenance of normal germ cell adenylate cyclase activity.

The present study clearly shows that Leydig cells, Sertoli cells and germ cells are impaired during unilateral cryptorchidism, although the reasons for this impairment are still unclear. Since 
the Leydig cells of the cryptorchid testis behave, morphologically and functionally, like chronically hCG-stimulated cells (de Kretser et al., 1979; Kerr et al., 1979), it is possible that seminiferous tubules normally produce substances which inhibit LH action on the Leydig cells (de Kretser, Kerr, Rich, Risbridger \& Dobos, 1980).

This study was supported by grants from Norwegian Research Council for Science and the Humanities (NAVF), World Health Organization (WHO), Rockefeller Foundation, Landsforeningen mot Kreft (LMK) and Norsk Forening til Kreftens Bekjempelse. We thank Tone Varaas and Drude Andersen for technical help; P. Torjesen for generously providing the human FSH and LH; and NIAMDD for the radioimmunoassay kits.

\section{References}

Amatayakul, K., Ryan, R., Vozumi, T. \& Albert, A. (1971) A reinvestigation of testicular-anterior pituitary relationships in the rat. I. Effects of castration and cryptorchidism. Endocrinology 88, 872-880.

Birnbaumer, L., Yang, P.-C., Hunzicker-Dunn, M., Bocksert, J. \& Duran, J.M. (1976) Adenylyl cyclase activities in ovarian tissues. I. Homogenization and conditions of assay in Graafian follicles and corpora lutea of rabbits, rats, and pigs: regulation by ATP, and some comparative properties. Endocrinology 99, 163-184.

Braun, T. \& Dods, R.F. (1975) Development of a $\mathrm{Mn}^{2+}$-sensitive "soluble" adenylate cyclase in rat testis. Proc. natn. Acad. Sci. U.S.A. 72, 1097-1101.

Christensen, A.K. \& Mason, N.R. (1965) Comparative ability of seminiferous tubules and interstitital tissue of rat testis to synthesize androgens from progesterone-4- ${ }^{14} \mathrm{C}$ in vitro. Endocrinology 76, 646656.

de Kretser, D.M., Sharpe, R.M. \& Swanston, I.A. (1979) Alterations in steroidogenesis and human chorionic gonadotropin binding in the cryptorchid rat testis. Endocrinology 105, 135-138.

de Kretser, D.M., Kerr, J.B., Rich, K.A., Risbridger, G. \& Dobos, M. (1980) Hormonal factors involved in normal spermatogenesis and following the disruption of spermatogenesis. In Testicular Development, Structure, and Function, pp. 107-115. Eds A. Steinberger \& E. Steinberger. Raven Press, New York.

Downs, R.W., Jr, Spiegel, A.M., Singer, M., Reen, S. \& Aurbach, G.D. (1980) Fluoride stimulation of adenylate cyclase is dependent on the guanine nucleotide regulatory protein. J. biol. Chem. 255, 949-954.

Eckstein, F., Cassel, D., Levkovitz, H., Lowe, M. \& Selinger, Z. (1979) Guanosine 5'-O-(2-thiodiphosphate). An inhibitor of adenylate cyclase stimulation by guanine nucleotides and fluoride ions. $J$. biol. Chem. 254, 9829-9834.

Gomes, W.R. \& Jain, S.K. (1976) Effect of unilateral and bilateral castration and cryptorchidism on serum gonadotrophins in the rat. J. Endocr. 68, 191-196.

Gordeladze, J.O. \& Hansson, V. (1980) $\mathrm{Mn}^{2+}$-dependent adenylyl cyclase $(A C)$ in rat testis: kinetic properties and optimalization of assay conditions. Int. $J$. Androl. 3, 539-552.
Gordeladze, J.O., Purvis, K., Clausen, O.P.F., Rommerts, F.F.G. \& Hansson, V. (1981) Cellular localization of $\mathrm{Mn}^{2+}$-dependent adenylyl cyclase (AC) in rat testis. Int. J. Androl. (in press).

Gupta, D., Rager, K., Zarzycki, J. \& Eichner, M. (1975) Levels of luteinizing hormone, follicle-stimulating hormone, testosterone and dihydrotestosterone in the circulation of sexually maturing intact male rats and after orchidectomy and experimental bilateral cryptorchidism. J. Endocr. 66, 183-193.

Hagenäs, L. \& Ritzen, E.M. (1976) Impaired Sertoli cell function in experimental cryptorchidism in the rat. Mol. cell Endocr. 4, 25-34.

Hagenäs, L., Ritzen, E.M., Svensson, J., Hansson, V. \& Purvis, K. (1978) Temperature dependence of Sertoli cell function. In Endocrine Approach to Male Contraception, pp. 449-458. Eds V. Hansson, M. Ritzen, K. Purvis \& F. S. French. Scriptor, Copenhagen.

Hansson, V., Purvis, K., Attramadal, A., Torjesen, P., Andersen, D. \& Ritzen, E.M. (1978) Sertoli cell function in the androgen insensitive (TFM) rat. Int. $J$. Androl. 1, 96-104.

Haug, E. \& Gautvik, K.M. (1976) Radioimmunoassay of rat prolactin and its use in measuring prolactin production by cultured pituitary cells. Acta endocr., Copenh. 82, 282-297.

Hsueh, A.J.W., Dufau, M.L. \& Catt, K.J. (1977) Gonadotropin-induced regulation of luteinizing hormone receptors and desensitization of $3^{\prime}: 5^{\prime}$-cyclic AMP and testosterone responses. Proc. natn. Acad. Sci. U.S.A. 74, 592-595.

Jahnsen, T. \& Hansson, V. (1980) Age dependent changes in FSH responsive adenylyl cyclase and FSH binding in rat testes. Int. J. Androl. 4, 55-63.

Jahnsen, T., Purvis, K., Birnbaumer, L. \& Hansson, V. (1980a) FSH and $\mathrm{LH} / \mathrm{hCG}$ responsive adenylyl cyclases in adult rat testes: methodology and assay conditions. Int. J. Androl. 3, 396-416.

Jahnsen, T., Gordeladze, J.O., Torjesen, P.A. \& Hansson, V. (1980b) FSH responsive adenylyl cyclase in rat testes: desensitization by homologous hormone. Arch. Androl. 5, 169-177.

Jahnsen, T., Purvis, K., Torjesen, P.A. \& Hansson, V. (1980c) Temporal relationship between hCG induced desensitization of the $\mathrm{LH} / \mathrm{hCG}$ responsive adenylyl cyclase and down-regulation of the $\mathrm{LH} / \mathrm{hCG}$ receptors in the rat testis. Arch. Androl. 6, 155-162. 
Kerr, J.B., Rich, K.A. \& de Kretser, D.M. (1979) Alterations of the fine structure and androgen secretion of the interstitial cells in the experimentally cryptorchid rat testis. Biol. Reprod. 20, 409-422.

Lowry, O.H., Rosebrough, N.F., Farr, A.L. \& Randall, R.J. (1951) Protein measurement with the folin phenol reagent. J. biol. Chem. 193, 265-275.

Ritzén, E.M., French, F.S., Weddington, S.C., Nayfeh, S.N. Hansson, V. (1974) Steroid binding in polyacrylamide gels. Quantitation at steady state conditions. J. biol. Chem. 249, 6597-6604.

Salomon, Y., Londos, C. \& Rodbell, M. (1974) A highly sensitive adenylate cyclase assay. Analyt. Biochem. 58, 541-548.

Walsh, P.C. \& Swerdlof, R.S. (1973) Experimental cryptorchism: effect on serum LH and FSH in the rat. Urol. Res. 1, 22-26.

Received 29 December 1980 